\title{
The Antiplaque Efficacy and Effectiveness of Activated Charcoal Toothpaste of Elaeis guineensis in Smokers
}

\author{
Uce Lestari $^{1 *}$, Syamsurizal ${ }^{2}$,Yustika Trisna ${ }^{1}$ \\ ${ }^{1}$ Department of Pharmacy, Faculty of Medicine and Health, University of Jambi \\ ${ }^{2}$ Department of Chemistry Education, Faculty of Education, University of Jambi \\ Kampus Pinang Masak, Jalan raya Jambi-Ma Bulian Km 15 Mendalo Darat, Jambi, 36361
}

Submitted 5 August 2020; Revised 25 November 2021; Accepted 04 December 2021; Published 30 December 2021

*Corresponding author: ucelestari@unja.ac.id

\begin{abstract}
Plaque on the teeth of smokers comes from cigarette smoke tar that settles on the surface of the teeth and roots of the teeth, causing the tooth surface to become rough and easier to stick with food debris and germs that will react making it easier for plaque to form. This study was aims to determine the safety and effectiveness of removing plaque in palm shell activated charcoal toothpaste with a concentration of $12 \%$ calcium carbonate combination of $25 \%$. The content of calcium carbonate as an abrasive against the dental plaque of active smokers. The method used was measurement the plaque index score according to Turesky before and after using toothpaste on 20 panelists of active smokers. The decrease in plaque index in the use of toothpaste by using Wilcoxon's non-parametric statistical test, namely $\mathrm{P}=$ 0.000 ( $\mathrm{Sig}<0.05$ ). The results showed that toothpaste in the first week was able to reduce dental plaque by $59 \%$ compared to positive control by $45 \%$ and without activated charcoal by $34 \%$. Toothpaste and positive control in the second week were able to remove dental plaque by $100 \%$, while toothpaste without activated charcoal and calcium carbonate was only able to remove dental plaque by $68 \%$. It can be concluded that palm shell activated charcoal toothpaste with a concentration of $12 \%$ combined with $25 \%$ calcium carbonate is safe and effective in removing plaque on the teeth of smokers.
\end{abstract}

Keywords: dental plaque, efficacy, palm shells

\section{Efikasi dan Efektifitas Pasta Gigi Antiplak Arang Aktif dari Elaeis guineensis pada Perokok}

\begin{abstract}
Abstrak
Plak pada gigi perokok berasal dari tar asap rokok yang mengendap pada permukaan gigi dan akar gigi sehingga menyebabkan permukaan gigi menjadi kasar dan lebih mudah ditempeli oleh sisa makanan dan kuman yang akan bereaksi sehingga mempermudah timbulnya plak. Penelitian ini bertujuan untuk mengetahui keamanan dan efektifitas menghilangkan plak pada pasta gigi arang aktif cangkang sawit dengan konsentrasi 12\% kombinasi kalsium karbonat sebesar 25\%. Kandungan kalsium karbonat sebagai abrasif terhadap plak gigi perokok aktif. Metode yang digunakan adalah pengukuran skor indeks plak menurut Turesky sebelum dan sesudah menggunakan pasta gigi terhadap 20 panelis perokok aktif. Penurunan indeks plak pada penggunaan pasta gigi dengan menggunakan uji statistik non parametrik Wilcoxon yaitu $\mathrm{P}=0.000(\mathrm{Sig}<0.05)$. Hasil penelitian menunjukkan bahwa pasta gigi pada minggu pertama mampu mengurangi plak gigi sebesar 59\% dibandingkan dengan kontrol positif sebesar $45 \%$ dan tanpa arang aktif sebesar 34\%. Pasta gigi dan kontrol positif pada minggu kedua mampu menghilangkan plak gigi sebesar $100 \%$, sedangkan pasta gigi tanpa arang aktif dan kalsium karbonat hanya mampu menghilangkan plak gigi sebesar 68\%. Dapat disimpulkan bahwa pasta gigi arang aktif cangkang sawit dengan konsentrasi 12\% kombinasi kalsium karbonat sebesar 25\% aman dan efektif menghilangkan plak pada gigi perokok.
\end{abstract}

Kata Kunci: plak gigi, efikasi, cangkang sawit 


\section{Introduction}

Kesehatan gigi dan mulut merupakan suatu hal yang harus mendapatkan perhatian lebih, karena kesehatan gigi dan mulut dapat mempengaruhi kualitas kehidupan, termasuk fungsi bicara, pengunyahan, dan rasa percaya diri. Menurut Riskesdas tahun 2019 menyatakan bahwa jumlah masyarakat Indonesia yang mengalami masalah pada kesehatan gigi dan mulut berada pada angka yang tinggi yaitu $62,9 \% .{ }^{24}$ Berdasarkan hal tersebut, maka gigi dan mulut sangat penting untuk dilakukan perawatan, jika tidak akan menimbulkan masalah pada gigi seperti timbulnya plak.

Menurut Suriamah et al. (2019), plak gigi merupakan deposit lunak dari mikroorganisme melekat pada permukaan gigi dan berada dalam suatu polimer matriks bakteri dan saliva. Salah satu penyebab timbulnya plak pada gigi yaitu rokok. ${ }^{25}$ Berdasarkan data dari Fauzi et al. (2018), jumlah perokok laki-laki di Indonesia usia $\geq 15$ tahun pada tahun 2018 masih berada pada angka yang tinggi (62,9\%) dan masih menjadi pravelensi perokok laki-laki tertinggi di dunia. ${ }^{26}$ Mekanisme timbulnya plak pada gigi perokok yaitu berasal dari tar yang terdapat dalam asap rokok yang mengendap pada permukaan gigi dan akar gigi sehingga akan menyebabkan permukaan gigi menjadi kasar dan lebih mudah ditempeli oleh sisa makanan dan kuman yang akan bereaksi sehingga mempermudah timbulnya plak (Mardiati et al., 2013). Untuk mengatasi hal tersebut maka dapat digunakan adsorben yang memiliki kemampuan sebagai antiplak seperti arang aktif. Untuk mengatasi hal tersebut maka dapat digunakan adsorben yang memiliki kemampuan sebagai antiplak seperti arang aktif.

Arang aktif adalah arang yang konfigurasi atom karbonnya dibebaskan dari ikatan dengan unsur lain, serta pori dibersihkan dari senyawa lain sehingga permukaan dan pusat aktif menjadi luas. ${ }^{2}$ Hal ini dapat meningkatkan daya serap terhadap kotorankotoran yang terdapat pada gigi penyebab terbentuknya plak. Daya serap arang aktif erat hubungannya dengan sifat keaktifan karbon tersebut. Apabila suatu adsorbat terkontak dengan butiran arang aktif, maka molekulmolekul adsorbat tertarik pada permukaan pori dan tertahan ditempat tersebut melalui gaya-gaya yang lemah. ${ }^{3}$ Arang aktif cangkang sawit memiliki kemampuan daya serap yang lebih tinggi jika dibandingkan dengan arang aktif dari tempurung kelapa. Berdasarkan uji pendahuluan arang aktif yang berasal dari cangkang sawit yang di aktivasi secara fisika memiliki daya serap sebesar 761,46 $\mathrm{mg} / \mathrm{g} .{ }^{4}$ Sedangkan daya serap adsorpsi iodine pada tempurung kelapa sebesar $580 \mathrm{mg} / \mathrm{g} .{ }^{5}$ Nilai angka iodine yang tinggi menunjukkan besarnya daya adsorpsi dari adsorben. Berdasarkan nilai daya serap iodine tersebut menunjukkan bahwa daya serap arang aktif cangkang sawit terhadap plak berpotensi tinggi untuk diaplikasikan sebagai sediaan pasta gigi.

Pasta gigi adalah bahan pembantu yang digunakan untuk membersihkan gigi secara mekanis dari sisa makanan, menghilangkan plak, dan bau tak sedap pada mulut. ${ }^{1}$ Sediaan pasta gigi yang beredar dipasaran ada 2 jenis yaitu sediaan pasta dan sediaan gel (transparan). Sediaan pasta memiliki keunggulan dibandingkan sediaan gel karena dapat mempertahankan $\mathrm{pH}$ saliva sebelum kembali ke keadaan normal. ${ }^{6}$ Arang aktif yang dikombinasikan dengan bahan abrasif pada pasta gigi dapat menghambat mekanisme pembentukan plak karena dapat menetralkan asam hasil metabolisme bakteri plak. ${ }^{7}$

Berdasarkan penelitian sebelumnya oleh Syamsurizal et al. (2019) pasta gigi arang aktif cangkang sawit dengan konsentrasi $12 \%$ yang mengandung karbon untuk menyerap nikotin pada gigi perokok sehingga memiliki efektifitas sebagai pemutih gigi dan dapat menghilangkan plak pada perokok secara in vitro. Untuk mengetahui kemampuan arang aktif cangkang sawit sebagai antiplak pada gigi manusia maka dilakukan penelitan lanjutan secara klinis pada fase 1 yang telah memiliki ethical clereance dengan nomor B/558/UN21.8/PT/2020. Pada fase ini dilakukan pengujian terhadap manusia normal yang tidak memiliki riwayat penyakit. 


\section{Materials and methods}

\subsection{Alat}

Alat yang akan digunakan dalam penelitian ini adalah furnace(Naberthem), grinder machine, ayakan 200 mesh, timbangan digital (metteler Toledo), oven (Merck), tanur (Naberthem), desikator (Duran), pipet tetes, beaker glass (pyrex), gelas ukur (pyrex), krusibel (pyrex), erlenmeyer (pyrex), cawan petri (pyrex), batang pengaduk (pyrex), cawan penguap, kaca arloji (pyrex), corong (pyrex), kertas saring, waterbath, mortir dan stamfer, sudip, kertas perkamen, kaca objek, cover glass, $\mathrm{pH}$ meter, viskometer brookfield (DV2T), sikat gigi, dan tube.

\subsection{Bahan}

Bahan yang digunakan dalam penelitian ini yaitu cangkang sawit, Na CMC (Sari Kimia), kalsium karbonat (Brataco), natrium benzoat (Brataco), natrium lauril sulfat (Sari Kimia), oleum menthae piperitae (Brataco), sorbitol 70\% (Brataco), aquadest (Sari Kimia), metilen blue (Sari Kimia), larutan iodium 0,1 $\mathrm{N}$ (Brataco), larutan natrium tiosulfat 0,1 $\mathrm{N}$ (Brataco), amilum 1\% (Brataco), pasta gigi merk formula charcoal, dan disclosing solution (Sari Kimia).

\subsection{Penyediaan dan Pengolahan Sampel}

Sampel cangkang sawit (Elaeis guineensis) diperoleh dari Pabrik PT. Sumbertama Nusa Pertiwi Sungai Gelam. Cangkang dipisah dari serabut dari isi buahnya serta pengotor lainnya. Cangkang sawit ditimbang sebanyak $2 \mathrm{~kg}$. Setelah itu, dicuci dengan air mengalir, kemudian dijemur dibawah cahaya matahari langsung sampai kering

\subsection{Pembuatan Arang}

Cangkang sawit yang telah dikeringkan kemudian dikarbonasi dalam pembakaran dengan api bebas hingga menjadi arang, kemudian arang didinginkan dan dihaluskan menjadi serbuk arang, lalu diayak dengan ayakan 200 mesh. $^{2}$

\subsection{Pembuatan Arang Aktif}

Pembuatan arang aktif cangkang sawit dengan cara aktivasi fisika. serbuk arang aktif dimasukkan ke dalam cawan penguap lalu di panaskan dengan suhu tinggi pada suhu $600^{\circ} \mathrm{C}$ selama 3 jam. $^{2}$

\subsection{Uji Sifat Fisik Arang Aktif}

2.6.1 Uji Kadar Air.

Arang aktif cangkang sawit ditimbang sebanyak 1 gram dan dimasukkan ke dalam kaca arloji yang telah ditimbang sebelumnya, lalu dimasukkan ke dalam oven pada suhu $\pm 105^{\circ} \mathrm{C}$ selama 3 jam. Sampel didinginkan dan disimpan dalam desikator selama 15 menit lalu ditimbang berat hingga konstan. Kadar air dapat dihitung dengan menggunakan rumus ${ }^{8}$ :

Kadar air $(\%)=\frac{\mathrm{w}_{1}-w_{2}}{\mathrm{w}_{1}} \times 100 \%$

Keterangan:

$\mathrm{W} 1$ = Bobot sampel sebelum pemanasan $(\mathrm{g})$ $\mathrm{W} 2=$ Bobot sampel setelah pemanasan $(\mathrm{g})$

\subsubsection{Uji Kadar Abu.}

Arang aktif cangkang sawit ditimbang sebanyak 1 gram dan dimasukkan ke dalam cawan penguap yang telah diketahui bobotnya, kemudian dimasukkan ke dalam oven dengan suhu yang tinggi pada suhu $600^{\circ} \mathrm{C}$ hingga seluruh sampel menjadi abu. Setelah itu, didinginkan dan disimpan dalam desikator selama 15 menit lalu ditimbang hingga berat konstan. Kadar abu dapat dihitung dengan menggunakan rumus ${ }^{8}$.

$$
\operatorname{Kadar} \text { abu }(\%)=\frac{\mathrm{w}_{1}-w_{2}}{\mathrm{w}_{1}} \times 100 \%
$$

Keterangan:

$\mathrm{w} 1=$ Bobot sampel sebelum pemanasan $(\mathrm{g})$

$\mathrm{w} 2=$ Bobot sampel setelah pemanasan $(\mathrm{g})$

\subsubsection{Uji Daya Serap Metilen Biru.}

Arang aktif cangkang sawit ditimbang $500 \mathrm{mg}$, di masukkan aquadest ke dalam beaker glass sebanyak $100 \mathrm{~mL}$ kemudian ditetesi dengan 5 tetes metilen biru. Arang aktif dimasukkan ke dalam beaker glass yang berisi larutan metilen biru. Jika warna berubah menjadi tidak berwarna menunjukkan bahwa arang aktif mempunyai daya adsorbens. ${ }^{9}$

2.6.4 Uji Daya Serap Iodin. 
Menurut ASTM (1999) dalam Lestari et al. (2019), arang aktif cangkang sawit dipanaskan dalam oven pada suhu $105^{\circ} \mathrm{C}$ selama 1 jam. Lalu didinginkan dalam desikator selama 30 menit. Sebanyak 0,25 $\mathrm{g}$ arang aktif cangkang sawit tersebut ditambahkan $50 \mathrm{~mL}$ larutan iodium $0,1 \mathrm{~N}$, diaduk selama 15 menit. Kemudian diambil $10 \mathrm{~mL}$ filtrat, dititrasi dengan $\mathrm{Na} 2 \mathrm{~S} 2 \mathrm{O} 3$ 0,1 N. Bila warna kuning dari larutan telah samar, selanjutnya ditambah larutan amilum $1 \%$ sebagai indikator. Titrasi kembali secara teratur hingga warna biru hilang. Penyerapan terhadap iodium dapat dihitung dengan menggunakan rumus:

$$
\operatorname{DSI}(\%)=\frac{\left(\mathrm{mL} \text { sampel }-\frac{\mathrm{T} \times \mathrm{C} 1}{\mathrm{C} 2}\right) \times \mathrm{W} 1 \times \mathrm{Fp}}{\text { gr sampel }}
$$

Keterangan:

$$
\begin{array}{ll}
\mathrm{DSI} & =\text { Daya Serap Iodine }\left(\mathrm{mg} \mathrm{g}^{-1}\right) \\
\mathrm{mL} \text { sampel } & =\text { Filtrat }(10 \mathrm{~mL}) \\
\mathrm{T} & =\text { Volume titrasi } \mathrm{Na}_{2} \mathrm{~S}_{2} \mathrm{O}_{3}(\mathrm{~mL}) \\
\mathrm{C} 1 & =\text { Konsentrasi } \mathrm{Na}_{2} \mathrm{~S}_{2} \mathrm{O}_{3}(\mathrm{~N}) \\
\mathrm{C} 2 & =\text { Konsentrasi iodine }(\mathrm{N}) \\
\mathrm{W} 1 & =\text { Berat iodine }\left(12.693 \mathrm{mg} \mathrm{mL}^{-1}\right) \\
\mathrm{Fp} & =\text { Faktor pengenceran }(5)
\end{array}
$$

\subsection{Formula Pasta Gigi}

Formula yang digunakan merupakan formula pasta gigi yang memiliki sifat fisik paling baik berdasarkan penelitian terdahulu dari Syamsurizal et al. (2019), dengan konsentrasi arang aktif cangkang sawit $12 \%$. Formula pasta gigi dapat dilihat pada tabel 1 .

\subsection{Pembuatan Pasta Gigi}

Tabel 1. Formula Pasta Gigi
$\mathrm{Na}$ CMC dikembangkan di atas air panas sebanyak $10 \mathrm{ml}$ dan didiamkan selama 15 menit dan diaduk hingga homogen (massa 1). Kalsium karbonat digerus dalam lumpang, lalu ditambahkan arang aktif cangkang sawit yang telah ditambahkan larutan sorbitol $70 \%$ diaduk hingga homogen (massa 2). Massa 1 ditambahkan ke massa 2 dan diaduk higga homogen (massa 3). Natrium benzoat dilarutkan dalam sisa air sebanyak ad 100 $\mathrm{ml}$, diaduk homogen dan dimasukkan ke dalam massa 3, digerus homogen. Natrium lauril sulfat ditambahkan ke dalam massa 3, diaduk homogen sampai terbentuk massa pasta. Oleum menthae piperitae dimasukkan terakhir, diaduk sampai homogen dan kemudian dimasukkan ke dalam tube. ${ }^{10}$

\subsection{Evaluasi Pasta Gigi}

2.9.1 Organoleptis.

Parameter organoleptis yang diamati meliputi tekstur, warna, dan bau secara visual dari formula pasta gigi pada penyimpanan suhu ruangan. Uji ini dilakukan selama 4 minggu $1 .{ }^{1}$

\subsubsection{Homogenitas.}

Menurut Rowe et al. (2009) yang telah dimodifikasi oleh Syamsurizal et al. (2019), pasta gigi dioleskan pada kaca objek dan

\begin{tabular}{|c|c|}
\hline Bahan & Konsentrasi $(\% \mathrm{~b} / \mathrm{b})$ \\
\hline Arang aktif cangkang sawit & 12 \\
\hline $\mathrm{Na} \mathrm{CMC}$ & 1 \\
\hline Kalsium karbonat & 25 \\
\hline Sorbitol $70 \%$ & 28 \\
\hline Natrium benzoat & 1 \\
\hline Natrium lauril sulfat & 1 \\
\hline Minyak permen & 0,3 \\
\hline Aquadest ad & 100 \\
\hline
\end{tabular}
ditutup dengan cover glass. Amati susunan partikel yang tidak homogeny pada kaca objek, lalu dicatat. Sediaan yang memiliki homogenitas yang baik harus menunjukkan tidak adanya gelembung udara, gumpalan, dan partikel yang terpisah serta tidak adanya benda asing yang tampak. Uji ini dilakukan 
selama 4 minggu.

\subsubsection{Uji pH}

Menurut Rowe et al. (2009) yang telah dimodifikasi oleh Syamsurizal et al. (2019), pengujian $\mathrm{pH}$ dilakukan dengan cara mencelupkan elektroda dari $\mathrm{pH}$ meter ke formula, ditunggu hingga layar pada $\mathrm{pH}$ meter menunjukkan angka yang stabil. Uji ini dilakukan selama 4 minggu.

\subsubsection{Uji stabilitas (cycling test)}

Diambil $8 \mathrm{~g}$ sediaan disimpan pada suhu $4^{\circ} \mathrm{C}$ selama 24 jam lalu dipindahkan ke oven dengan suhu $40^{\circ} \mathrm{C}$ selama 24 jam dan perlakuan ini adalah 1 siklus. Pengujian ini dilakukan sebanyak 6 siklus atau 6 hari dan diamati perubahan fisik meliputi organoleptis, homogenitas, $\mathrm{pH}$, tinggi busa dan daya sebar. ${ }^{12}$

\subsubsection{Uji viskositas}

Penentuan viskositas dan sifat alir dilakukan dengan viskometer Brookfield. Pasta gigi dimasukkan ke dalam beaker glass $250 \mathrm{~mL}$, lalu spindle diturunkan ke dalam sediaan hingga batas yang ditentukan, lalu dicatat skalanya. ${ }^{13}$

\subsubsection{Uji daya sebar}

Pasta gigi ditimbang sebanyak $1 \mathrm{~g}$, kemudian diletakkan di tengah-tengah cawan petri yang sebelumnya ditimbang terlebih dahulu. Ditambahkan beban $50 \mathrm{~g}$ dan 100 $\mathrm{g}$ di atas cawan petri selama 1 menit setiap penambahan bahan. Diukur diameter sediaan yang menyebar. ${ }^{14}$

\subsubsection{Uji tinggi busa}

Diambil sedikit pasta gigi, lalu dimasukkan ke gelas ukur, dilarutkan dengan aquadest sebanyak $10 \mathrm{~mL}$. Gelas ukur ditutup lalu dikocok 10 kali dan diamati tinggi busa yang terbentuk. Dicatat volume akhir busa. ${ }^{15}$

\subsection{Uji Iritasi.}

Uji keamanan sediaan berupa uji iritasi, dilakukan oleh 20 orang panelis yang aktif perokok lebih dari 5 tahun dengan jenis kelamin laki-laki usia 25-55 tahun. Panelis diminta untuk menggunakan pasta gigi arang aktif cangkang sawit sebanyak 2 kali dalam 1 hari pada siang dan malam hari. Diamati reaksi yang terjadi setelah penggunaan pasta gigi seperti timbul bintik-bintik pada daerah gusi, rasa gatal di area sekitar mulut, gusi bengkak/berdarah dan sariawan. ${ }^{16}$

\subsection{Uji Kesukaan (Hedonik)}

Uji kesukaan dilakukan oleh 20 orang panelis mengenai warna, bau, rasa, bentuk, dan konsistensi. Uji ini dilakukan dengan menggunakan skala 1 sampai 7 yaitu:

$$
\begin{aligned}
& 1=\text { Sangat tidak suka } \\
& 2=\text { Tidak suka } \\
& 3=\text { Agak tidak suka } \\
& 4=\text { Netral } \\
& 5=\text { Agak suka } \\
& 6=\text { Suka } \\
& 7=\text { Sangatsuka }
\end{aligned}
$$

Kemudian dihitung interval nilai mutu rata-rata dari setiap panelis terhadap masingmasing sediaan dengan rumus sebagai berikut 17 :

$$
\begin{aligned}
P(\bar{x}-(1,96 & \left.\left.\times \frac{s}{\sqrt{n}}\right)\right) \leq \mu \\
& \leq\left(\bar{x}+\left(1,96 \times \frac{s}{\sqrt{n}}\right)\right) \\
\bar{x} & =\frac{\sum_{i=1}^{n} x_{i}}{n} \\
s & =\sqrt{\frac{\sum_{i=1}^{n} x_{i}}{n}}
\end{aligned}
$$

Keterangan:

$\mathrm{P} \quad=$ Interval nilai kesukaan

$\mathrm{N}$ = Banyaknya panelis

1,96= Koefisien standar deviasi pada $95 \%$

$\overline{\mathrm{X}}=$ Nilai mutu rata-rata;

$\mathrm{Xi}=$ Nilai mutu dari panelis ke $\mathrm{i}$

$\mathrm{S}=$ Simpangan baku nilai mutu

\subsection{Uji Efektifitas Pasta Gigi}

Persiapan Subjek Penelitian. Menurut Suriamah et al. (2019) yang telah dimodifikasi, panelis yang dipilih harus memenuhi kriteria inklusi dan eksklusi. Dimana kriteria inklusi yang dipenuhi yaitu berusia 25-55 tahun berdasarkan riset kesehatan dasar bahwa perokok aktif lebih dari lima tahun berada pada kisaran usia tersebut, riwayat merokok 
$\geq 5$ tahun, susunan gigi yang masih lengkap dan teratur, terdapat plak pada gigi, tidak ada riwayat penyakit, dan bersedia menjadi subjek penelitian. Sedangkang kriteria ekslusi yang harus dipenuhi yaitu menggunakan pasta gigi lain, menggunakan larutan penyegar mulut, dan menggunakan larutan pencuci mulut. Kemudian Panelis menyatakan kesediaannya dengan mengisikuisioner dan menandatangani surat pernyataan kesediaan menjadi subjek penelitian (Informed Consent).

Panelis dikelompokkan dalam tiga kelompok yaitu:

a. Kelompok pertama adalah pengujian klinis fase 1 pada kelompok yang menggosok gigi menggunakan pasta gigi dengan kandungan arang aktif cangkang sawit sebanyak 20 panelis.

b. Kelompok kedua adalah kelompok yang menggosok gigi menggunakan pasta gigi tanpa kandungan arang aktif cangkang sawit sebanyak 1 panelis yang bukan dari panelist kelompok pertama

c. Kelompok ketiga adalah kelompok yang menggosok gigi menggunakan pasta gigi merk Formula Charcoal yang diproduksi oleh pabrik OT (Orang Tua) sebanyak 1 panelis yang bukan dari kelompok pertama dan kedua.

\subsection{Pemeriksaan Plak}

Dilakukan dengan menggunakan disclosing solution diproduksi oleh Oxyfresh USA. Indeks plak dihitung dengan menjumlahkan permukaan yang terwarnai. ${ }^{27}$
Perhitungan indeks plak dilakukan sebelum dan setelah menggunakan pasta gigi selama 2 minggu dan dilakukan pengecekan setiap minggunya $^{18}$ dengan memperhatikan pengurangan stain (pewarnaan gigi) serta berkurangnya plak gigi sebelum dan sesudah menggunakan pasta gigi arang aktif cangkang sawit.

\subsection{Pengontrolan Plak}

Panelis diminta untuk menggunakan pasta gigi 2 kali sehari pada pagi dan malam hari. Pengamatan dilakukan selama 2 minggu dengan metode menyikat gigi dengan sikat gigi bulu lembut yang sama (diberikan oleh peneliti) dan menggunakan pasta gigi arang aktif cangkang sawit sepanjang bulu sikat gigi serta mengosok gigi selama kurang lebih 5 menit dengan gerakan gerakan bolak balik atas bawah .

\subsection{Penilaian skor plak gigi.}

Menurut Turesky et al yang dimodifikasi dari Quigley dan Hein. ${ }^{19}$ Pemeriksaan plak dilakukan terhadap seluruh gigi kecuali gigi molar ketiga. Peneliti telah melakukan uji kalibrasi pada satu orang panelist dan menghasilkan nilai Indek plak sebesar 0,43 yang mendekati dengan nilai indek plak pasta gigi komersil sebesar 0,50. Kriteria penilaian skor plak dapat dilihat pada tabel 2 .

Indeks plak yang diperiksa dihitung dengan menggunakan rumus:

$$
\text { Indeks plak }=\frac{\text { Total skor }}{\text { Jumlah permukaan yang diperiksa }}
$$

Tabel 2. Kriteria Penilaian Skor Plak ${ }^{19}$

\begin{tabular}{|c|c|}
\hline Skor & Kondisi \\
\hline 0 & Tidak ada plak \\
\hline 1 & Terdapat bercak-bercak plak yang terpisah pada bagian margin servikal dari gigi \\
\hline 2 & Terdapat lapisan tipis plak sampai setebal $1 \mathrm{~mm}$ pada bagian margin servikal dari gigi \\
\hline 3 & Terdapat lapisan plak lebih dari $1 \mathrm{~mm}$ yang kurang dari $1 / 3$ bagian mahkota \\
\hline 4 & Terdapat lapisan plak lebih dari $1 / 3$ hingga kurang dari $2 / 3$ bagian mahkota \\
\hline 5 & $\begin{array}{l}\text { Terdapat lapisan plak yang menutupi } 2 / 3 \text { bagian mahkota atau lebih dari } 2 / 3 \text { bagian mah- } \\
\text { kota }\end{array}$ \\
\hline
\end{tabular}




\subsection{Analisis Data}

Pada uji sifat fisik dilakukan secara deskriptif terhadap uji organoleptis, uji homogenitas, uji $\mathrm{pH}$, uji viskositas, uji daya sebar, dan uji tinggi busa. Pada uji cycling test dan uji efektifitas pasta gigi sebagai antiplak menggunakan uji statistik parametrik Paired t-test. Paired t-test digunakan untuk melihat perubahan sediaan pada suhu ekstrim dan melihat adanya penurunan plak pada pasta gigi arang aktif cangkang sawit. Syarat uji parametrik Paired t-test adalah sebaran data harus normal dan homogen dimana nilai sig $>0.05$. Jika pada uji parametrik Paired t-test tidak normal dan tidak homogen, maka dilakukan uji lanjut non parametrik menggunakan uji Wilcoxon.

\section{Result}

Analisis Sifat Fisiko Kimia Arang Aktif Cangkang Sawit meliputi pemeriksaan kadar air, kadar abu, daya serap metilen blue dan dara serap iodin. Adapun hasil rekapitulasi dar sifat fisiko kimia arang aktif cangkang sawit dapat dilihat pada tabel 3 .

\subsection{Evaluasi Sediaan Pasta Gigi}

Evaluasi sifat fisik pasta gigi meliputi uji organoleptis, homogenitas, pengukuran $\mathrm{pH}$, viskositas, daya sebar, tinggi busa, dan cycling test. Adapun hasil rekapitulasi dari evaluasi sifat fisik dari pasta gigi arang aktif cangkang sawit dapat dilihat pada tabel 4 .

Uji stabilitas dari pasta gigi arang aktif cangkang sawit sebelum dan setelah penyimpanan dapat dilihat pada tabel 5 .

Pengamatan plak gigi dapat dilakukan

dengan penggunaan disclosing solution.. Warna pink dari disclosing solution yang menempel pada gigi menandakan adanya plak. Pengamatan dilakukan pada responden perokok dengan hasil indeks plak dapat dilihat pada tabel 6 .

\section{Discussion}

Proses aktivasi dilakukan secara fisika. Aktivasi secara fisika dipilih karena arang aktif dibuat menjadi pasta gigi yang diaplikasikan ke gigi, selain itu penggunaan aktivasi arang aktif cangkang swait dengan menggunakan aktivasi secara kimia mempersulit untuk mendapatkan $\mathrm{pH}$ yang lebih aman dan sesuai dengan $\mathrm{pH}$ mulut yaitu 4-6,5.23

\subsection{Uji Kadar Air.}

Kadar air pada arang aktif mampu mempengaruhi daya serap baik terhadap cairan dan gas. Nilai kadar air yang dihasilkan dalam penelitian ini adalah 4,9\% telah memenuhi Standar Nasional Indonesia (SNI) dengan batasan maksimal yaitu 15\%.

\subsection{Uji Kadar Abu.}

Kadar abu arang aktif diuji untuk mengetahui kandungan oksida logam dalam bahan. Nilai kadar abu yang dihasilkan dalam penelitian ini adalah 7,33 \% yang telah memenuhi Standar Nasional Indonesia (SNI) dengan batasan maksimal yaitu $10 \%$. Jika kadar abu arang aktif yang tinggi dapat mempengaruhi daya adsorpsi baik terhadap larutan maupun gas.

\subsection{Daya Serap Metilen Biru}

Tabel 3. Rekapitulasi analisis sifat fisiko kimia arang aktif cangkang sawit

\begin{tabular}{lll}
\hline \multicolumn{1}{c}{ Kategori } & \multicolumn{1}{c}{ Hasil } & \multicolumn{1}{c}{ Parameter } \\
\hline Kadar air & $4,9 \% *$ & Syarat kadar air $\leq 15 \%$ (SNI 06-3730-1995) \\
Kadar abu & $7,33 \% *$ & Syarat kadar abu $\leq 10 \%$ (SNI 06-3730-1995) \\
Daya serap & $\begin{array}{l}\text { Terjadi perubahan warna biru } \\
\text { muda menjadi tidak berwarna* }\end{array}$ & $\begin{array}{l}\text { Terjadi perubahan warna biru muda menjadi } \\
\text { tidak berwarna (Lestari et al. 2017) }\end{array}$ \\
Daya serap iodine & $786,966 \mathrm{mg} / \mathrm{g}^{*}$ & $\begin{array}{l}\text { Syarat nilai daya serap iodine }>750 \mathrm{mg} / \mathrm{g} \\
\text { (SNI 06-3730-1995) }\end{array}$ \\
\hline
\end{tabular}

Keterangan: $(*)=$ Sesuai Parameter 
Tabel 4. Rekapitulasi evaluasi sifat fisik pasta gigi

\begin{tabular}{|c|c|c|}
\hline Kategori & Hasil & Parameter \\
\hline Organoleptis & $\begin{array}{l}\text { Warna hitam, bau mint, bentuk } \\
\text { semi padat dan konsis-tensi lem- } \\
\text { but* }\end{array}$ & $\begin{array}{l}\text { Stabil, tidak terjadi perubahan warna, bau } \\
\text { dan bentuk (Rowe et al., 2009). }\end{array}$ \\
\hline Homogenitas & Homogen* & Homogen (Rowe et al., 2009). \\
\hline $\mathrm{pH}$ & $7,07 * \pm 0,12$ & $\begin{array}{l}\text { Syarat } \mathrm{pH} \text { pasta gigi } 4,5-10,5 \text { (SNI 12- } \\
3524-1995) \text {. }\end{array}$ \\
\hline Viskositas & $33.225 \mathrm{cps}^{*} \pm 567,61$ & $\begin{array}{l}\text { Syarat viskositas pasta gigi } 20.000- \\
50.000 \mathrm{cps} \text { (SNI 12-3525-1995) }\end{array}$ \\
\hline Daya Sebar & $3,83 \mathrm{~cm} \pm 0,15$ & $\begin{array}{l}\text { Standar daya sebar sediaan semisolid } \\
\text { berkisar antara 3-5 cm (Yuliani., 2010). }\end{array}$ \\
\hline Tinggi Busa & $4,33 \mathrm{ml}^{*} \pm 0,29$ & Tidak ada standar tinggi busa pasta gigi \\
\hline Uji Iritasi & $\begin{array}{l}0 \% \text { timbul kemerahan pada gusi, } \\
0 \% \text { timbul rasa gatal di area sekitar } \\
\text { mulut, } 0 \% \text { gusi bengkak atau } \\
\text { berda-rah, dan } 0 \% \text { sariawan (tidak } \\
\text { terjadi iritasi)* }\end{array}$ & $\begin{array}{l}\text { Tidak menimbulkan iritasi (Matthew et } \\
\text { al., 2010). }\end{array}$ \\
\hline $\begin{array}{l}\text { Uji Kesukaan } \\
\text { (Hedonik) }\end{array}$ & $\begin{array}{l}\text { Warna }=5,85, \text { aroma }=6,61 \text {, Rasa } \\
=6,3 \text {, Bentuk }=6,18 \text {, dan konsis- } \\
\text { tensi }=6,15\end{array}$ & $\begin{array}{l}\text { Sangat tidak suka (1), tidak suka (2), agak } \\
\text { tidak suka(3), netral (4), agak suka(5), } \\
\text { suka(6), sangat suka(7) (SNI 12-2346- } \\
\text { 2006). }\end{array}$ \\
\hline
\end{tabular}

Keterangan: $(*)=$ Sesuai Parameter

Hasil mewakili rata-rata dari tiga replikasi $(\mathrm{n}=3)$ dan ditampilkan sebagai nilai rata-rata $\pm \mathrm{SD}$ (Standar Deviasi).

Tabel 5. Hasil Cycling Test Sebelum dan Sesudah Penyimpanan

\begin{tabular}{|c|c|c|}
\hline Kategori & Sebelum/Sesudah & $\mathbf{F}$ \\
\hline \multirow[t]{2}{*}{ Organoleptis } & Sebelum & $\begin{array}{l}\text { Warna hitam, bau mint, bentuk semi padat dan konsistensi } \\
\text { lembut* }\end{array}$ \\
\hline & Sesudah & $\begin{array}{l}\text { Warna hitam, bau mint, bentuk semi padat dan konsistensi } \\
\text { lembut* }\end{array}$ \\
\hline \multirow[t]{2}{*}{ Homogenitas } & Sebelum & Homogen* \\
\hline & Sesudah & Homogen* \\
\hline \multirow[t]{2}{*}{$\mathrm{pH}$} & Sebelum & $7,03 * \pm 0,15$ \\
\hline & Sesudah & $7 * \pm 0,1$ \\
\hline \multirow[t]{2}{*}{ Daya Sebar } & Sebelum & $3,83 \mathrm{~cm} * \pm 0,15$ \\
\hline & Sesudah & $3,6 \mathrm{~cm}^{*} \pm 0,1$ \\
\hline \multirow[t]{2}{*}{ Tinggi Busa } & Sebelum & $4,27 \mathrm{ml}^{*} \pm 0,25$ \\
\hline & Sesudah & $3,93 \mathrm{ml}^{*} \pm 0,21$ \\
\hline
\end{tabular}

Keterangan: $(*)=$ Sesuai Parameter 
Tabel 6. Indeks Plak Sebelum dan Sesudah Penggunaan Pasta Gigi Arang Aktif Cangkang Sawit

\begin{tabular}{cccccc}
\hline $\mathbf{K}$ & Sebelum & M1 & Turun & M2 & Turun \\
\hline $\mathrm{F}$ & $0,34 \pm 0,130$ & $14 \pm 0,09$ & $59 \%$ & 0,00 & $100 \%$ \\
$\mathrm{~K}(-)$ & 0.56 & 0,37 & $45 \%$ & 0,18 & $68 \%$ \\
$\mathrm{~K}(+)$ & 0.56 & 0,31 & $34 \%$ & 0,00 & $100 \%$ \\
\hline
\end{tabular}

Keterangan:

$\mathrm{F}=$ Kelompok Pasta Gigi Arang Aktif Cangkang Sawit

$\mathrm{K}(-)=$ Kelompok Pasta Gigi Arang Aktif

$\mathrm{K}(+)=$ Kelompok Pasta Gigi Merk Formula

Penentuan daya serap terhadap metilen biru dilakukan dengan tujuan untuk mengetahui kemampuan adsorpsi arang aktif yang dihasilkan terhadap larutan berwarna dan mengetahui luas permukaan yang dimiliki oleh adsorben. ${ }^{21}$ Arang aktif cangkang sawit yang diberi 5 tetes metilen biru menunjukkan perubahan warna dari warna biru muda menjadi tidak berwarna. Hal ini menunjukkan arang aktif memiliki daya adsorben. ${ }^{23}$

\subsection{Daya Serap Iodine}

Daya adsorpsi arang aktif terhadap iod berhubungan dengan luas permukaan dari arang aktif. Semakin besar angka iod maka semakin besar kemampuannya dalam mengadsorpsi adsorbat atau zat terlarut. Penambahan larutan iod berfungsi sebagai adsorbat yang akan diserap oleh arang aktif sebagai adsorbennya. Terserapnya larutan iod ditunjukkan dengan adanya pengurangan konsentrasi larutan iod. Pengukuran konsentrasi iod sisa dapat dilakukan dengan menitrasi larutan iod dengan natrium tiosulfat $0,1 \mathrm{~N}$ dan indikator yang digunakan yaitu amilum. Nilai daya serap iod pada penelitian ini adalah 786,966 mg/g. Nilai daya serap iod yang diperoleh telah memenuhi Standar Nasional Indonesia (SNI) arang aktif teknis. Menurut SNI 06-3730-1995, nilai daya serap iod minimal yaitu $750 \mathrm{mg} / \mathrm{g}^{8,23}$.hal ini menunjukan bahwa arang aktif memiliki kemampuan menyerap plak dari perokok.

Adapun keberharuan dari penelitian ini adalah dilakukan secara uji in vivo atau uji klinis terhadap aplikasi pada manusia langsung setelah dilakukan dari awal mulanya terhadap uji kualitatif dan kuantitatif, uji pada gigi hewan sapi yang telah mati serta dilakukan pada gigi tikus dan terakhir pada gigi manusia perokok lebih dari 5 tahun.

Dari hasil yang didapat bahwa pasta gigi arang aktif memiliki kemampuan yang sama dengan pasta gigi komersil dalam menyerap atau menghilangkan plak gigi.

Adapun resiko yang timbul saat menggunakan pasta gigi ini dalam jangka waktu yang lama adalah terjadi pengikisan pada email gigi sehingga disarankan kepada pengguna untuk mengunakan nya dikombinasi dengan penggunaan pasta gigi atau 3 kali seminggu setelah dihasilkan plak gigi sudah tidak muncul kembali.

\subsection{Organoleptis}

Uji organoleptis bertujuan untuk melihat penampilan fisik suatu sediaan yang telah dibuat yang meliputi tekstur, warna dan bau. ${ }^{+}$Pada penelitian ini hasil yang diperoleh bahwa pada semua sediaan yang direplikasi tidak mengalami perubahan bau, warna, bentuk dan konsistensi. Hal ini berarti tidak terjadi reaksi kimia antara bahan-bahan yang digunakan karena salah satu tanda terjadinya reaksi kimia terhadap bahan-bahan dalam campuran adalah terjadinya perubahan warna

\subsection{Homogenitas}

Menurut Rowe et al. (2009) yang telah dimodifikasi oleh Syamsurizal et al. (2019), sediaan pasta gigi dikatakan homogen bila tidak terdapat gumpalan-gumpalan kecil, partikel-partikel kasar, gelembung udara dan tidak terjadi pemisahan antar masing-masing 
sediaan serta tidak adanya benda asing yang tampak.

Hasil uji homogenitas pada penelitian ini pasta gigi yang dibuat tidak mengalami pemisahan, homogen dan stabil. Hal ini sesuai dengan syarat mutu sediaan pasta gigi (SNI 12-3526-1995) yang menyebutkan bahwa sediaan pasta gigi harus homogen, tidak terlihat adanya gelembung udara, gumpalan dan partikel yang terpisah yang berarti semua sediaan gel pasta gigi yang dihasilkan mempunyai susunan yang homogen. ${ }^{20}$

\section{7. $\mathrm{pH}$}

Pengukuran $\mathrm{pH}$ (Power of Hydrogen) merupakan parameter fisikokimia yang penting pada sediaan topical karena $\mathrm{pH}$ berkaitan dengan efektivitas zat aktif, stabilitas zat aktif dan sediaan, serta kenyamanan sewaktu digunakan. Dari data tersebut, rata rata nilai $\mathrm{pH}$ yang terdapat pada pasta gigi selama 4 minggu mulai dari $\mathrm{pH}$ 7,07 sampai $\mathrm{pH} 7,1$. Hal tersebut menunjukkan kadar $\mathrm{pH}$ yang terdapat pada pasta gigi memiliki $\mathrm{pH}$ yang netral. Nilai $\mathrm{pH}$ yang diperoleh telah memenuhi SNI 12-3525-1995 yaitu 4,5$10,5 .^{20^{\prime}}$

\subsection{Viskositas}

Tujuan pengujian viskositas untuk mengetahui kekentalan pada pasta gigi arang aktif cangkang sawit. Viskositas yang semakin tinggi menggambarkan sediaan yang semakin kental dan sebaliknya. Dari data diatas, diketahui hasil rata-rata viskositas semua sediaan yang direplikasi yaitu 33.225 cps. Nilai viskositas yang diperoleh telah memenuhi SNI 12-3525-1995 yaitu 20.000 $50.000 \mathrm{cps}^{.20,23}$

\subsection{Daya Sebar}

Uji daya sebar sediaan pasta gigi dimaksudkan untuk mengetahui kemampuan menyebar pasta gigi saat dioleskan. Kemampuan menyebar adalah karakteristik yang penting, karena mempengaruhi transfer bahan aktif pada target dengan dosis yang tepat, kemudahan penggunaan, tekanan yang diperlukan agar dapat keluar dari kemasan dan penerimaan oleh konsumen. Semakin besar nilai diameter daya sebar maka semakin besar luas permukaan yang bisa dijangkau oleh sediaan pasta gigi. Luas penyebaran berbanding lurus dengan kenaikan penambahan beban, semakin besar beban yang ditambahkan daya sebar yang dihasilkan semakin luas. Standar daya sebar sediaan semisolid berkisar antara 3-5 cm. ${ }^{22}$ Dari data pada tabel 3 rata-rata nilai daya sebar untuk semua sediaan yang direplikasi yaitu 3,83. Data yang diperoleh telah memenuhi standar.

\subsection{Tinggi Busa}

Uji pembentukan busa bertujuan untuk melihat banyaknya busa yang dihasilkan oleh pasta gigi untuk mengangkat kotoran dan membersihkan mulut saat menyikat gigi. Tidak ada syarat tinggi busa untuk suatu produk pasta gigi. Hal ini dikaitkan pada nilai estetika yang disukai konsumen. Busa yang dihasilkan dari suatu sediaan pasta gigi umumnya dipengaruhi oleh konsentrasi detergen yang digunakan. Pada basis pasta gigi ini digunakan SLS (sodium laureth sulfate) sebagai detergen. SLS merupakan surfaktan anionik yang memiliki karakteristik sebagai pembentuk busa yang baik dan memiliki daya pembersih yang tinggi. Berdasarkan hasil evaluasi pembentukan busa, sediaan pasta gigi dapat membentuk busa dengan baik. Hasil pengukuran kemampuan pembentukan busa tersebut menunjukkan kemampuan suatu detergen untuk menghasilkan busa sehingga pembuangan plak, debris, material alba dan sisa makanan menjadi lebih mudah. ${ }^{20}$

\subsection{Cycling Test}

Cycling test merupakan uji stabilitas dipercepat yang dilakukan untuk mengetahui kestabilan dari pasta gigi arang aktif pada saat penyimpanan. Produk yang tidak stabil akan memiliki kecenderungan cepat rusak sehingga kehilangan fungsi dan manfaatnya dan tidak akan disukai oleh konsumen.

Uji cycling test ini dilakukan sebanyak 6 siklus. Sediaan gel disimpan pada suhu dingin $\pm 4^{\circ} \mathrm{C}$ selama 24 jam lalu dikeluarkan dan ditempatkan pada suhu $\pm 40{ }^{\circ} \mathrm{C}$, proses ini dihitung 1 siklus 12 . Perlakuan diulangi sebanyak 6 siklus dan dilakukan pengamatan 
dengan parameter organoleptik, homogenitas, $\mathrm{pH}$, daya sebar dan tinggi busa.

Pemeriksaan setelah cycling test menunjukkan bahwa pasta gigi arang aktif cangkang sawit stabil dan tidak mengalami perubahan aroma, warna, bentuk dan konsistensi serta tidak terjadi pemisahan antar masing-masing sediaan.

Hasil uji analisa statistik terhadap $\mathrm{pH}$ sediaan yang diuji secara parametrik menggunakan paired sample t-test $\mathrm{p}=0.423$ $(\operatorname{sig}>0,05)$ menunjukkan bahwa tidak terdapat perbedaan yang nyata, berarti tidak ada pengaruh antara sediaan dengan penyimpanan suhu ekstrim.

Hasil uji analisa statistik terhadap tinggi busa sediaan yang diuji secara parametrik menggunakan paired $t$-test $\mathrm{p}=0.032(\mathrm{sig}<0.05)$ menunjukkan bahwa terdapat perbedaan yang nyata yang berarti ada pengaruh suhu penyimpanan ekstrim terhadap tinggi busa sediaan. Perubahan nilai tinggi busa masih memenuhi standar.

Hasil uji analisa statistik terhadap daya sebar sediaan setelah cycling test yang diuji secara parametrik menggunakan paired sample t-test $\mathrm{p}=0.02(\operatorname{sig}<0.05)$ menunjukkan bahwa terdapat perbedaan yang nyata yang berarti ada pengaruh suhu penyimpanan ekstrim terhadap daya sebar sediaan.

\subsection{Uji Iritasi}

Uji iritasi dilakukan pada 20 panelis perokok yang sehat secara fisik, tidak memiliki riwayat alergi ataupun penyakit lainnya dan telah menyatakan kesediaannya sebagai panelis. Reaksi yang diamati adalah alergi di daerah pengujian, yaitu area sekitar gigi dan mulut dengan gejala timbul bintikbintik kemerahan pada gusi, timbul rasa gatal di area sekitar mulut, gusi bengkak atau berdarah, dan sariawan. ${ }^{16}$ Berdasarkan hasil uji iritasi yang telah dilakukan pada 20 panelis didapatkan $0 \%$ timbul kemerahan pada gusi, $0 \%$ timbul rasa gatal di area sekitar mulut, $0 \%$ gusi bengkak atau berda-rah, dan $0 \%$ sariawan. Hasil ini menunjukkan bahwa pasta gigi arang aktif cangkang sawit tidak membuat iritasi dan aman untuk digunakan.

\subsection{Uji Kesukaan (Hedonik)}

Uji hedonik dilakukan untuk melihat preferensi konsumen dalam hal warna, aroma, rasa, bentuk dan konsistensi. Tes ini juga merupakan faktor yang menentukan keputusan konsumen untuk menerima atau menolak suatu produk. Dari tabel 4, dapat diketahui bahwa respon kesukaan dari tiap panelis terhadap warna produk yaitu dalam rentang nilai 5,85-6,55 (agak suka sampai suka), aroma 6,61-7,09 (suka sampai sangat suka), rasa 6,3-6,8 (suka), bentuk 6,18-6,62 (suka), dan konsistensi 6,15-6,65 (suka). Dapat disimpulkan bahwa rata-rata panelis menyukai produk pasta gigi arang aktif cangkang sawit.

Uji Efektifitas Pasta Gigi Arang Aktif Cangkang Sawit, Pasta Gigi Tanpa Arang Aktif, dan Pasta Gigi Formula Charcoal

Berdasarkan hasil penelitian dapat dilihat plak menghilang setelah dilakukan penyikatan dengan menggunakan pasta gigi arang aktif cangkang sawit setelah 2 minggu. Hasil penurunan indeks plak pada penggunaan pasta gigi dengan menggunakan uji statistik non parametrik Wilcoxon yaitu $\mathrm{p}=0.000$ $(\mathrm{Sig}<0.05)$, sehingga dapat dikatakan terjadi penurunan indeks plak yang signifikan.

Pasta gigi arang aktif cangkang sawit mampu mengurangi plak gigi lebih baik yaitu sebesar 59\% dibandingkan dengan pasta gigi komersil (formula charcoal) sebesar $45 \%$ dan pasta gigi tanpa arang aktif sebesar 34\% pada minggu ke-1. Pada minggu ke-2 pasta gigi arang aktif cangkang sawit dan pasta gigi komersil mampu menghilangkan plak gigi sebesar $100 \%$, sedangkan pasta gigi tanpa arang aktif mampu menghilangkan plak gigi sebesar $68 \%$.

Variasi penurunan indeks plak pada penelitian ini dapat terjadi karena beberapa faktor. Lingkungan fisik seperti anatomi posisi gigi dan friksi atau gesekan oleh makanan yang dikunyah dapat mempengaruhi proses pembentukan plak gigi. Jenis makanan, yaitu keras dan lunak dapat mempengaruhi pembentukan plak pada permukaan gigi. Plak banyak terbentuk jika lebih banyak mengkonsumsi makanan lunak, terutama makanan yang mengandung karbohidrat jenis 
sukrosa, karena akan menghasilkan dekstran dan levan yang memegang peranan penting dalam pembentukan matriks plak. ${ }^{1}$

Penyikatan gigi dengan menggunakan pasta gigi arang aktif dapat menurunkan indeks plak secara bermakna. Hal tersebut disebabkan terdapat arang aktif dan bahan abrasif yang dapat membersihkan dan memoles permukaan gigi tanpa merusak email. Pasta gigi yang mengandung bahan pembersih (detergent) yang fungsinya menurunkan tegangan permukaan dan melonggarkan ikatan debris dengan gigi yang akan membantu gerakan pembersihan sikat gigi. Adanya kandungan arang aktif, bahan abrasif dan detergent menyebabkan pembuangan plak, debris, material alba, dan sisa makanan menjadi lebih mudah. ${ }^{10}$

\section{Conclusion}

Berdasarkan hasil penelitian yang telah dilakukan, maka dapat disimpulkan bahwa formula pasta gigi arang aktif cangkang sawit dengan konsentrasi arang aktif 12\% memiliki sifat fisik yang baik. Pasta gigi arang aktif cangkang sawit mampu mengurangi plak gigi lebih baik yaitu sebesar 59\% dibandingkan dengan pasta gigi komersil (formula charcoal) sebesar $45 \%$ dan pasta gigi tanpa arang aktif sebesar $34 \%$ pada minggu ke- 1 . Pada minggu ke-2 pasta gigi arang aktif cangkang sawit dan pasta gigi komersil mampu menghilangkan plak gigi sebesar $100 \%$, sedangkan pasta gigi tanpa arang aktif mampu menghilangkan plak gigi sebesar $68 \%$.

\section{References}

1. Suriamah, N., R. Lessang and Y. Kemal. 2019. Effectiveness Of Toothpaste Containing Propolis, Tea Tree Oil, And Sodium Monofluorophosphate Against Plaque And Gingivitis. International Journal of Applied Pharmaceutics. 11(1): 114-116.

2. Sudrajat, R dan S. Soleh. 1994. Petunjuk Teknik Pembuatan Arang Aktif, Pusat Litbang Hasil Hutan Dan Sosek Kehutanan, Bogor.

3. Sukardjo. 2002. Kimia Fisika, PT Rineka Cipta, Jakarta.
4. Syamsurizal, U. Lestari and Nurhasanah. 2019. Formulation Of Toothpaste Activated Charcoal From Palm Shell (Elaeis guineensis Jacg) As Teeth Whitening For Nicotine Addicts. Int. J. Pharm. Sci. Rev. Res. 58(1):9-12.

5. Polii, F. F. 2017. Pengaruh Suhu Dan Lama Aktifasi Terhadap Mutu Arang Aktif Dari Kayu Kelapa. Jurnal Industri Hasil Perkebunan. 12(2): 21-28.

6. Ligtenberg, A. J. M. 2006. The Effect Of Tootbrushing On Secretion Rate, $\mathrm{pH}$ And Buffering Capacity Of Saliva. International Journal Of Dental Hygiene. 5: 104-105.

7. Pertiwi, U. I., Y. K. Eriwati and B. Irawan. 2017. Surface changes of enamel after brushing with charcoal toothpaste. Journal of Physics.

8. Standar Nasional Indonesia. 1995. Arang Aktif Teknis, SNI 06-3730-1995, Badan Sandarisasi Nasional, Jakarta.

9. Lestari, U., F. Farid dan P. M. Sari. 2017. Formulasi dan Uji Sifat Fisik Lulur Body Scrub Arang Aktif Dari Cangkang Sawit (Elaeis guineensis Jacg.) Sebagai Detoksifikasi. Jurnal Sains Dan Teknologi Farmasi. 9(1): 74-79.

10. Lachman, L., Lieberman, H. A., dan Kanig, J. L. 1994. Teori dan Praktek Farmasi Industri, Edisi Ketiga, UI Press, Jakarta.

11. Rowe, R. C., P. J. Sheskey and S. C. Owen. 2009. Handbook Of Pharmaceutical Excipients, American Pharmaceutical Association, USA.

12. Butler, H. 2000. Poacher's Perfumes, Cosmetics And Soap, 10th Edition, Kluwer Academy Publicher, London.

13. Chandira, R. M., Pradeep, A. Pasupathi, D. Bhowmik, B. Chiranjib, K. K. Jayakar, K. P. Tripathi and S. Kumar. 2010. Design, Development And Formulations Of Antiacne Dermatology Gel. Jurnal Of Chemical And Pharmaceutical Research. 2(1): 401-414.

14. Ogboji, J., I. Y. Chindo., A. Jauro., D. E. A. Boryo and Lawal N. M. 2018. Formulation, physicochemical evaluation and antimicrobial activity of green 
toothpaste on streptococcus mutans. International Journal of Advanced Chemistry. 6 (1): 108-113.

15. Akotakar, A. M, R. R. Thenge., A. V. Patil., A. B. Ghonge and M. B. Bhaltadak. 2018. Formulation and comparative standardization of toothpaste. International Journal of Pharmaceutical Science and Research. 3(4): 12-15.

16. Matthew, J., Zirwas, M. D. and S. Otto. 2010. Toothpaste Allergy Diagnosis and Management. Journal Clinical Aesthetic Dermatology. 3(5): 42-47.

17. Standar Nasional Indonesia. 2006. Petunjuk Pengujian Organoleptik dan atau Sensori, SNI 12-2346-2006, Badam Standarisasi Nasional, Jakarta.

18. Halim, H and T. A. Salsabila. 2020. The Effectiveness Of Using Siwak Toothpaste On Plaque Accumulation In Fixed Orthodontic Appliances Users. Asian Journal of Pharmaceutical and Clinical Research. 13(3): 113-115.

19. Marya, C. M. 2011. A Textbook Of Public Health Dentistry, Jaypee Brothers Medical Publishers, New Delhi.

20. Standar Nasional Indonesia. 1995. Pasta Gigi, SNI 12-3524-1995, Badan Standarisasi Nasional, Jakarta.

21. Bao, Y and G. Zhang. 2012. Study of Adsorption Characteristics of Methylene Blue onto Activated Carbon Made by Salix Psammophila. Energy Procedia. 16: 1141 - 1146.

22. Yuliani, S. H. 2010. Optimasi Kombinasi Campuran Sorbitol, Gliserol, dan Propilenglikol dalam Gel Sunscreen Ekstrak Etanol Curcuma manggai. Majalah Farmasi Indonesia. 21(2): 83-89.

23. Lestari, U., F. Farid and A. Fudholi. 2019. Formulation and Effectivity Test of Deodorant from Activated Charcoal of Palm Shell as Excessive Sweat Adsorbent on Body. Asian Journal of Pharmaceutical and Clinical Research. 12(10): 193-196.

24. Balitbang, Kemenkes, 2019, Riset Kesehatan Dasar, Jakarta

25. Suriamah, N., R. Lessang and Y. Kemal. 2019. Effectiveness Of Toothpaste Containing Propolis, Tea Tree Oil, And
Sodium Monofluorophosphate Against Plaque And Gingivitis. International Journal of Applied Pharmaceutics. 11(1): 114-116.

26. Fauzi, R., M. A. Ma'ruf, Bonita, N. Puspawati, K. Soewarso, A. Antojo, T. S. Bam. 2018. Hubungan Terpaan Iklan, Promosi, Sponsor Rokok Dengan Status Merokok Di Indonesia, Ikatan Ahli Kesehatan Masyarakat Indonesia, Jakarta.

27. Lestari U. 2021, Uji Aktivitas Pasta Gigi Arang Aktif Cangkang Sawit (Elaeis guineensis) Antiplak Pada Perokok Secara Invitro, Scientia Jurnal Farmasi dan Kesehatan Volume 10 (2) ; Hal 177 $-186$. 